\title{
Different Patterns Of Nutrient Cycling In Contiguous Phytophysiognomies Of Atlantic Forest, Brazil
}

\author{
Luis Fernando Tavares de Menezes ${ }^{1}$, Rodrigo Camara de Souza ${ }^{2}$, \\ Marcos Gervasio Pereira ${ }^{2}$ (D), Fábio Ribeiro Pires ${ }^{1}$, Bruno Santanna Fanticelle ${ }^{1}$, \\ Paulo Batista Araujo-Filho ${ }^{3}$ \\ ${ }^{1}$ Universidade Federal do Espirito Santo - UFES, São Mateus/ES, Brasil \\ ${ }^{2}$ Universidade Federal Rural do Rio de Janeiro - UFRRJ, Seropédica/RJ, Brasil \\ ${ }^{3}$ Instituto Nacional de Pesquisas da Amazônia - INPA, Manaus/AM, Brasil
}

\begin{abstract}
The present study aimed to evaluate fine aboveground litterfall, deposition of nitrogen and phosphorus from total litterfall and leaf litter decomposition in areas of tall forest (Mata Alta) and low forest on sandy soils (Mussununga) in southeastern Brazil. Fine litterfall was collected monthly for two years (from June/2007 to May/2009) in 10 conical collectors $\left(0.25 \mathrm{~m}^{2}\right)$ in each phytophysiognomy ( 1 ha plots). The material was subsequently separated into leaves, branches, flowers and fruits, and unidentified material. Leaf decomposition rates were evaluated using 15 litterbags, three of which were collected every 30 days. Higher litterfall occurred in both phytophysiognomies during the rainy season, with leaves predominating. The lowest litterfall, nutrient input, and leaf litter decomposition values appeared to be nutrient conservation strategies, contributing to the ecological functioning of the Mussununga where soil fertility was lower than in the Mata Alta.
\end{abstract}

Keywords: decomposition, ecological functioning, litterfall, tropical forest. 


\section{INTRODUCTION}

Litterfall and decomposition play critical roles in the productivity of forest systems and help promote tropical forest growth through efficient nutrient recycling (Pimenta et al., 2011; Marafiga et al., 2012). However, the naturally low fertility of most tropical forest soils can limit litterfall and nutrient input (Kaspari et al., 2008). Estimates of litterfall and decomposition rates, and the nutrient content of litter, are fundamental to our understanding of the biogeochemical functioning of those ecosystems therefore, especially given predicted climatic alterations (Parsons et al., 2014).

On a global scale, climate exerts a significant influence on the ecological processes of litterfall (Zhang et al., 2008) and decomposition (Aerts, 1997). At a local scale, microclimatic conditions, such as soil fertility (Parsons et al., 2014), soil moisture, and temperature, which depend on the structure and diversity of the arboreal community, control litterfall and decomposition (Menezes et al., 2010; Bianchin et al., 2016). The diversity of tree species strongly influences litter decomposition at smaller spatial scales (Scheer et al., 2011; Bonanomi et al., 2013) due to variations in litter chemical quality, which is related to nutrient concentrations and $\mathrm{C}: \mathrm{N}$ ratios (Zhang et al., 2014).

There is information regarding fine litterfall, chemical content, and/or litter decomposition in different Atlantic Forest physiognomies (Moraes et al., 1999; Menezes et al., 2010; Pimenta et al., 2011; Scheer et al., 2011; Marafiga et al., 2012; Pereira et al., 2012; Freire et al., 2014; Sloboda et al., 2017). Fine litterfall is composed of leaves, branches $\leq 2 \mathrm{~cm}$ in diameter, reproductive material, and unidentified material $<2 \mathrm{~mm}$ (Vitousek, 1984). However, few studies have focused on nutrient cycling in contiguous vegetation formations in this biome that experience the same climatic regimes but demonstrate abrupt variations in terms of vegetation structure, floristic composition, and soil fertility.

The present study aimed to evaluate fine aboveground litterfall, nutrient concentration and deposition in total litterfall, and leaf litter decomposition in two contiguous physiognomies of Atlantic Forest that differ strongly in terms of their floristics and soil fertility, seeking to better understand the spatial variations that can occur in those key processes of ecosystem functioning.
We tested the hypothesis that fine aboveground litterfall, nutrient input, and leaf litter decomposition rates are lower in a low forest area on sandy soils (Mussununga) due to the lower natural soil fertility and lower forest structure in comparison to a contiguous tall forest area (Mata Alta), in southeastern Brazil.

\section{MATERIAL AND METHODS}

\subsection{Study area}

The present study was undertaken in the Vale Natural Reserve which occupies an area of approximately $22,000 \mathrm{ha}$, in the municipality of Linhares $\left(19^{\circ} 06^{\prime}-19^{\circ} 18^{\prime} \mathrm{S} ; 39^{\circ} 45^{\prime}-40^{\circ} 19^{\prime} \mathrm{W}\right)$, in Espírito Santo State, Brazil. The regional climate is tropical hot and humid (type Aw), with a rainy austral summer season and dry austral winter (Alvares et al., 2013). The total annual rainfall and mean temperature during the first study year (year 1: June/2007 to May/2008) were $975.8 \mathrm{~mm}$ and $24.9^{\circ} \mathrm{C}$, respectively (Figure 1);

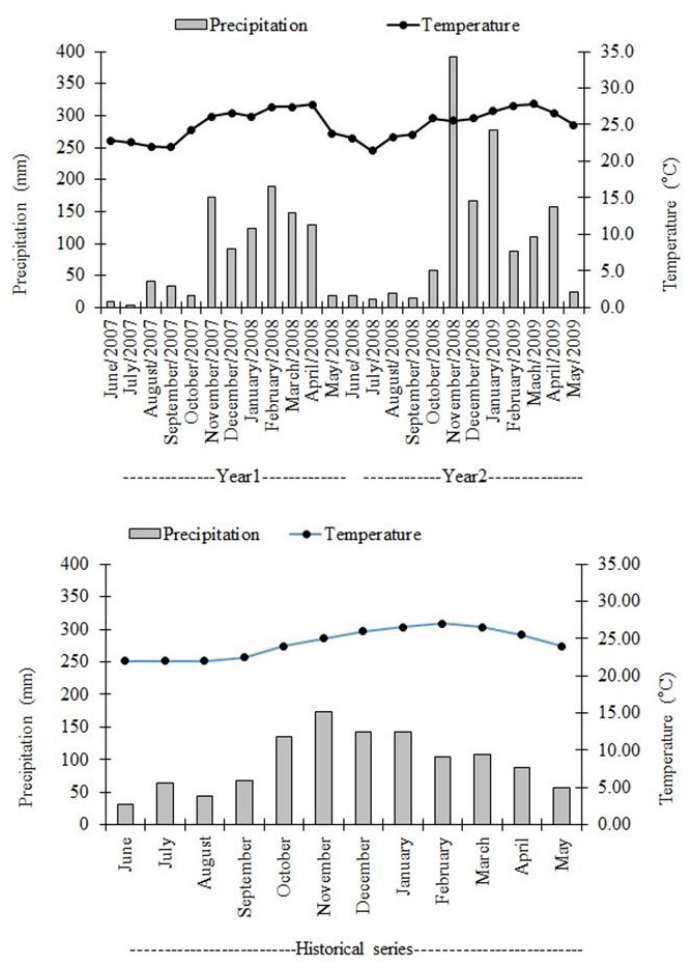

Figure 1. Monthly values of accumulated rainfall and mean temperatures during year 1 (June/2007 to May/2008), year 2 (June/2008 to May/2009) and according to the historical series, in Linhares, Espírito Santo State, Brazil. 
and $1,337.4 \mathrm{~mm}$ and $25.2{ }^{\circ} \mathrm{C}$, respectively during the second year (year 2: June/2008 to May/2009). As such, the accumulated rainfall in year 1 was approximately $362 \mathrm{~mm}$ less than year 2 . The climatic data were obtained from the weather station at Linhares maintained by the Capixaba Institute for Research, Technical Assistance and Rural Extension (Incaper), which is located approximately $27 \mathrm{~km}$ away from the study area. According to the historical series, the total annual rainfall and mean temperature for the areas were $1,159.0 \mathrm{~mm}$ and $24.4^{\circ} \mathrm{C}$, respectively (Clima Tempo, 2019).

The Reserve is dominated by Seasonal Semi-Deciduous Forest, also known as "Tabuleiro" (upland) forest, although other forest physiognomies such as Mata Alta (Tall Forest) and Mussununga are also present. We selected two contiguous one-hectare areas in these latter phytophysiognomies. The areas of Mata Alta present high tree species richness (271 species distributed among 55 families ha-1), which can reach up to $40 \mathrm{~m}$ in height and form a closed canopy (Peixoto et al., 2008). Mussununga forests occur in patches within the Mata Alta, with trees presenting heights of between 7 and $10 \mathrm{~m}$ (rarely reaching $20 \mathrm{~m}$ ) that form a discontinuous canopy with lower species richness than the Mata Alta (79 species distributed

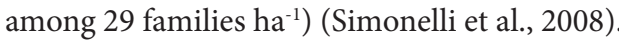

Mussununga shows higher floristic similarity with nearby areas of restinga (nearshore, sandy-soil vegetation) than with Mata Alta (Giaretta et al., 2013). Mata Alta forests occur on clayey or clayey-sandy soils, classified as Yellow Argisol (Ultisol), while Mussununga vegetation occurs on sandy Spodosol (Garay et al., 1995). According to the abovementioned authors, the topsoil in the Mata Alta demonstrates higher fertility when compared to the Mussununga area (Table 1).

\subsection{Fine litterfall}

In each area, the fine aboveground litterfall was sampled using 10 conical collectors $\left(0.25 \mathrm{~m}^{2}\right.$ in diameter) made of $1 \mathrm{~mm}$ nylon mesh, at $1.30 \mathrm{~m}$ above ground level. The collectors were allocated at a distance of $50 \mathrm{~m}$ from each other, distributed in three parallel delineated lines, spaced at a distance of $150 \mathrm{~m}$ from each other, in the center of each area. This systematized arrangement of collectors aimed to avoid the edge effect on litterfall. This material was collected monthly during years 1 and 2 and was taken to the laboratory for separation into fractions: leaf, branch ( $\leq 2 \mathrm{~cm}$ in diameter), flower and fruit, and unidentified material $<2 \mathrm{~mm}$ fractions. Afterwards, the material was dried in a forced air circulation oven $\left(70{ }^{\circ} \mathrm{C}, 72 \mathrm{~h}\right)$.

We calculated the daily fine litterfall $\left(\mathrm{g} \mathrm{m}^{-2}\right.$ day $\left.^{-1}\right)$ using the equation:

$D F L=[($ mean of litterfall $/ C A) / I D C]$

where: $\mathrm{DFL}=$ daily fine litterfall, $\mathrm{CA}=$ collector area $\left(=0.25 \mathrm{~m}^{2}\right)$, and IDC = interval, in days, between two successive collections ( $=30$ days).

The mean annual fine litterfall $\left(\mathrm{Mg} \mathrm{ha}^{-1}\right.$ year $\left.^{-1}\right)$ was then estimated using the equation (Lopes et al., 2002):

$A F L=(M L * 10,000) / C A$

where: $\mathrm{AFL}=$ mean annual fine litterfall, $\mathrm{MFL}=$ mean monthly fine litterfall $\left(\mathrm{Mg} \mathrm{ha}^{-1} \mathrm{month}^{-1}\right)$, and $\mathrm{CA}=$ collector area.

\subsection{Nutrients in total fine litterfall}

We pooled the total monthly litterfall fractions obtained in year 1 to form a composite sample per collector, in each area. Then, three out of 10 collectors were randomly selected per month in each area to obtain three samples composed of total litterfall to determine nitrogen $(\mathrm{N})$ and phosphorus $(\mathrm{P})$ concentrations (Tedesco et al., 1995). This procedure aimed to optimize chemical analysis. Afterwards, we estimated the nutrient content in total litterfall based on the product between the total litterfall dry mass deposited monthly in the collectors and its nutrient

Table 1. Chemical attributes of the topsoil $(0-10 \mathrm{~cm})$ in the Mata Alta and Mussununga within the upland (Tabuleiro) forests of the Vale Natural Reserve, in Linhares, Espírito Santo, Brazil. Source: adapted from Garay et al. (1995).

\begin{tabular}{|c|c|c|c|c|c|c|c|c|c|c|c|c|c|c|c|}
\hline \multirow{2}{*}{ Phytophysiognomy } & Clay & Silt & Sand & C & $\mathbf{N}$ & $\mathbf{C} / \mathbf{N}$ & pH & $\mathbf{P}$ & \multirow{2}{*}{$\mathbf{K}^{+}$} & $\mathrm{Ca}^{+2}$ & $\mathrm{Mg}^{+2}$ & $\mathbf{N a}^{+}$ & $\mathrm{H}^{+}+\mathrm{Al}^{3+}$ & SB & \\
\hline & & & $\%$ & & & & $\overline{\mathrm{H}_{2} \mathrm{O}}$ & $\mathrm{mg} \mathrm{kg}^{-1}$ & & \multicolumn{5}{|c|}{$\mathrm{cmol}_{\mathrm{c}} \mathrm{kg}^{-1}$} & \\
\hline Mata Alta & 7 & 5 & 88 & 0.86 & 0.07 & 12 & 5.6 & 2.80 & 0.07 & 1.73 & 0.44 & 0.05 & 2.61 & 2.29 & 4.9 \\
\hline Mussununga & 1 & 5 & 94 & 1.16 & 0.07 & 17 & 4.6 & 1.15 & 0.05 & 0.38 & 0.50 & 0.04 & 6.03 & 0.97 & 7.0 \\
\hline
\end{tabular}

$\mathrm{SB}=$ sum of bases; $\mathrm{CEC}=$ total cation exchange capacity. 
content, in each area. We presented the mean annual values of both nutrient concentration and content in the total litterfall.

\subsection{Leaf litter decomposition}

Leaf litter decomposition was evaluated using 15 litterbags placed on the ground near the conical collectors in each phytophysiognomy. The bags $(25 \times 25 \mathrm{~cm})$ were made from $4 \mathrm{~mm}$ nylon mesh (Menezes et al., 2010). Approximately $10 \mathrm{~g}$ of leaf litter obtained from the conical collectors was placed in each sack. Three litterbags were collected every 30 days for 150 days. The remaining materials in the litterbags at each collection time were oven dried $\left(65^{\circ} \mathrm{C}, 48 \mathrm{~h}\right)$ and weighed, resulting in measures of mass loss by subtracting the weight at each collection period from the initial mass (10 g)

The decomposition constant $\left(\mathrm{g} \mathrm{g}^{-1}\right.$ day $\left.^{-1}\right)$ was estimated using the equation of decreasing mass (Thomas \& Asakawa, 1993):

$X_{t}=X_{0} * e^{-k t}$

where: $X_{t}=$ dry mass of the material remaining after $t$ days, $\mathrm{X}_{0}=$ the dry mass of the material originally placed in the sacks at $\mathrm{t}_{0}$, and $\mathrm{k}=$ decomposition constant.

The half-life of the material $\left(\mathrm{T}_{1 / 2}\right)$, corresponding to the time required for the decomposition of $50 \%$ of the original mass, was calculated using the k value obtained from the following equation (Rezende et al., 1999):

$T_{1 / 2}=[\ln (2) / k]$

where: $\mathrm{T}_{1 / 2}=$ half-life of the material, and $\mathrm{k}=$ decomposition constant.

\subsection{Statistical analysis}

The data for fine litterfall (total and fractions) were submitted to the Kolmogorov-Smirnov test for normality. We evaluated the effects of the phytophysiognomy (Mata Alta $\times$ Mussununga) and the month of collection within each year (year $1 \times$ year 2 ) on fine litterfall by ANOVA Repeated Measures Design. We considered the values of fine litterfall (total and fractions) obtained from the collectors per month of the year in question as dependent variables and the collection dates (the total number of collection months in the year) as "within effects"; the phytophysiognomy was considered a "between effects" predictor.

When we observed a significant effect from the phytophysiognomy on annual fine litterfall (total and fractions), we proceeded with the analysis of variance (One-Way ANOVA), using the Levene test. We compared the means using the Student $t$ test when the variances demonstrated homoscedasticity, or the Mann-Whitney nonparametric test when that premise was not respected. We also verified the effect of phytophysiognomy on the nutrients in the total fine litterfall as described above. The influence of climatic factors (monthly rainfall and mean temperatures) on litterfall (total and leaves) was evaluated using the Spearman correlation test. We considered the climatic data obtained for years 1 and 2 and the historical series. All of those analyses were run on STATISTICA version 8.0 software, considering $\mathrm{p}<0.05$.

In relation to the decomposition experiment, we obtained the mass loss curve, as well as the exponential model that resulted in the $\mathrm{k}$ value and the $\mathrm{T}_{1 / 2}$, using analysis of variance ( $\mathrm{F}$ test, $\mathrm{P}<0.05$ ) of the rates of decomposition, using SigmaPlot software for Windows version 12.0

\section{RESULTS}

\subsection{Fine litterfall}

We observed significant interactions between phytophysiognomy and the collection months in year 1 for total litterfall $(\mathrm{F}=3.1286 ; \mathrm{P}=0.000649)$, leaves $(\mathrm{F}=5.3474 ; \mathrm{P}=0.000000)$, and branches $(\mathrm{F}=2.68976$; $\mathrm{P}=0.003026)$; and in the means between the years for total litterfall $(\mathrm{F}=2.4865 ; \mathrm{P}=0.006074)$, leaves $(\mathrm{F}=4.1297 ; \mathrm{P}=0.000018)$, and branches $(\mathrm{F}=3.51886$; $\mathrm{P}=0.000160)$. There was also significant effect of the collection month in year 1 for total litterfall $(\mathrm{F}=14.0000$; $\mathrm{P}=0.000000)$, leaves $(\mathrm{F}=31.7494 ; \mathrm{P}=0.000000)$, branches $(\mathrm{F}=3.67203 ; \mathrm{P}=0.000092)$, flowers and fruits $(\mathrm{F}=2.39028 ; \mathrm{P}=0.008406)$, and unidentified material $(\mathrm{F}=4.43046 ; \mathrm{P}=0.000006)$.

We also observed a significant effect of the collection month in year 2 for total litterfall $(F=10.1567$; $\mathrm{P}=0.000000)$, leaves $(\mathrm{F}=27.2023 ; \mathrm{P}=0.000000)$, branches $(\mathrm{F}=3.16577 ; \mathrm{P}=0.000568)$, and in the mean between the years for total litterfall $(\mathrm{F}=18.0145$; 
$\mathrm{P}=0.000000)$, leaves $(\mathrm{F}=37.1201 ; \mathrm{P}=0.000000)$, branches $(\mathrm{F}=3.47863 ; \mathrm{P}=0.000185)$, and unidentified material $(\mathrm{F}=2.5746 ; \mathrm{P}=0.004499)$.

Total litterfall was significantly higher in the Mata Alta forest (years 1 and 2, mean between the years), when compared to the Mussununga (Table 2). We also observed higher values for branch (year 1), and flower and fruit (year 2 and means between the years) deposition in the Mata Alta. There were no significant differences between the phytophysiognomies in terms of the leaf and unidentified material fractions during those years or in the means between the years.

Leaves represented more than $50 \%$ of the total annual litterfall in the phytophysiognomies during both year 1 (Mata Alta: 65\%; Mussununga: 68\%) and year 2 (Mata Alta: 56\%; Mussununga: 62\%) (Table 2). Considering the means for those two years, leaves contributed 62 and $65 \%$ of the total annual litter deposited in the Mata Alta and Mussununga forests, respectively.

A significant effect was observed in terms of the collection year on litterfall in both the Mata Alta and the Mussununga forests. The Mata Alta phytophysiognomy demonstrated significantly higher leaf and total litterfall deposition during year 1 when compared to year 2 (Table 2). The same tendency was observed in the Mussununga forest, with significantly higher leaf, flower and fruit, and total litterfall deposition in year 1 than in year 2 .
In general, we observed the highest leaf biomass and total litterfall in the months with higher rainfall. During year 1, the highest leaf and total litterfall deposition in the Mata Alta forest occurred between November/2007 and January/2008, while the peak of leaf and total litterfall deposition in the Mussununga forest occurred in December/2007 (Figure 2). The highest leaf and total litterfall during year 2 were observed between January/2008 and February/2008 in both phytophysiognomies.

Considering the climatological data from the study period, we observed a significant positive correlation between mean accumulated monthly precipitation and leaf deposition, in the Mata Alta (years 1 and 2) and Mussununga (year 2) (Table 3). A significant positive correlation was also observed between precipitation and total litterfall, in the Mussununga (year 2). There was also a significant positive correlation between the mean monthly temperatures and leaf deposition in the Mata Alta (year 1) and Mussununga (year 2), and total litterfall in the Mussununga (year 2)

In relation to the historical series, we observed a significant positive correlation between precipitation and leaf deposition in the Mata Alta (both years 1 and 2) and in the Mussununga (year 2), and between precipitation and total litterfall in the Mata Alta (year 1) and Mussununga (year 2) (Table 3). The same significant positive correlation between mean temperature and leaf deposition and total litterfall occurred in both Mata Alta and Mussununga. There was also a

Table 2. Annual litterfall (total and fractions) during year 1 (June/2007 to May/2008) and year 2 (June/2008 to May/2009) in the Mata Alta and Mussununga phytophysiognomies within the upland (Tabuleiro) forests of the Vale Natural Reserve, in Linhares, Espírito Santo State, Brazil*.

\begin{tabular}{|c|c|c|c|c|c|}
\hline \multirow{3}{*}{ Phytophysiognomy } & \multicolumn{5}{|c|}{ Fraction of litter $\left(\mathrm{Mg} \mathrm{ha}^{-1}\right.$ year $\left.^{-1}\right)$} \\
\hline & Leaf & Branch & $\begin{array}{c}\text { Flower and } \\
\text { fruit }\end{array}$ & $\begin{array}{c}\text { Unidentified } \\
\text { material }\end{array}$ & Total \\
\hline & \multicolumn{5}{|c|}{ Year 1} \\
\hline Mata Alta & $8.96 \mathrm{Aa}(1.45)$ & $3.47 \mathrm{Aa}(2.20)$ & $1.10 \mathrm{Aa}(0.56)$ & $0.97 \mathrm{Aa}(0.30)$ & $14.50 \mathrm{Aa}(3.21)$ \\
\hline \multirow[t]{2}{*}{ Mussununga } & $8.20 \mathrm{Aa}(1.75)$ & $1.58 \mathrm{Ba}(1.37)$ & $0.79 \mathrm{Aa}(0.53)$ & $0.83 \mathrm{Aa}(0.54)$ & $11.40 \mathrm{Ba}(3.07)$ \\
\hline & \multicolumn{5}{|c|}{ Year 2} \\
\hline Mata Alta & $5.43 \mathrm{Ab}(1.18)$ & $1.69 \mathrm{Aa}(0.49)$ & $1.32 \mathrm{Aa}(0.96)$ & $1.26 \mathrm{Aa}(0.72)$ & $9.71 \mathrm{Ab}(1.73)$ \\
\hline \multirow[t]{2}{*}{ Mussununga } & $4.28 \mathrm{Ab}(1.43)$ & $1.49 \mathrm{Aa}(1.59)$ & $0.36 \mathrm{Bb}(0.32)$ & $0.83 \mathrm{Aa}(0.34)$ & $6.96 \mathrm{Bb}(2.98)$ \\
\hline & \multicolumn{5}{|c|}{ Mean } \\
\hline Mata Alta & 7.20 A $(0.89)$ & $2.58 \mathrm{~A}(1.14)$ & $1.21 \mathrm{~A}(0.61)$ & $1.11 \mathrm{~A}(0.36)$ & $12.10 \mathrm{~A}(1.71)$ \\
\hline Mussununga & 6.24 A (1.49) & $1.54 \mathrm{~A}(1.33)$ & $0.57 \mathrm{~B}(0.34)$ & $0.83 \mathrm{~A}(0.40)$ & $9.18 \mathrm{~B}(2.74)$ \\
\hline
\end{tabular}

* The values indicate the means obtained from 10 replicates, followed by the standard deviation (in parentheses). Values followed by different uppercase letters within the same litter fraction and the same year indicate significant differences between the phytophysiognomies, as determined by the parametric Student $t$ test or the nonparametric Mann-Whitney test $(\mathrm{P}<0.05)$. Values followed by different lowercase letters within the same litter fraction and the same phytophysiognomy indicate significant differences between those years by the parametric Student $t$ test or the nonparametric Mann-Whitney $\mathrm{U}$ test $(\mathrm{P}<0.05)$. 


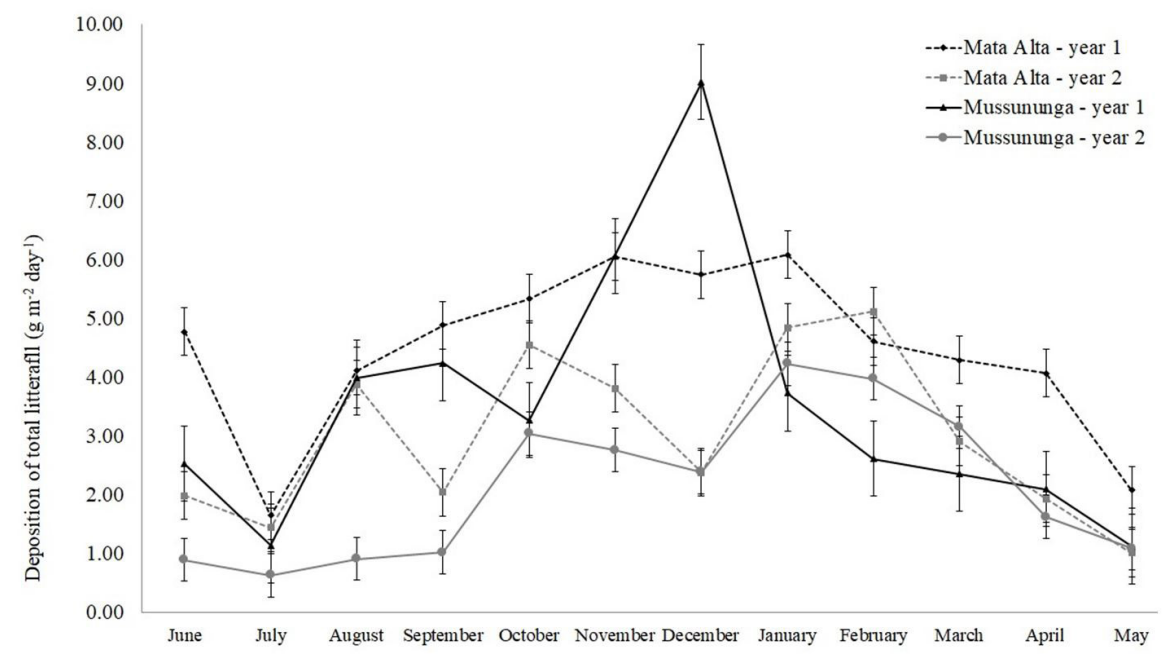

Figure 2. Monthly total litterfall during year 1 (June/2007 to May/2008) and year 2 (June/2008 to May/2009) in the Mata Alta and Mussununga phytophysiognomies within the upland (Tabuleiro) forests of the Vale Natural Reserve, in Linhares, Espírito Santo State, Brazil.

Table 3. Values of the Spearman correlation coefficients between monthly leaf fraction and total litterfall and the climatic variables of mean monthly temperature (Tmed) and accumulated monthly rainfall (Pacum) during year 1 (June/2007 to May/2008), year 2 (June/2008 to May/2009), and in relation to the historical series, in the Mata Alta and Mussununga phytophysiognomies within the upland (Tabuleiro) forests of the Vale Natural Reserve, in Linhares, Espírito Santo State, Brazil.

\begin{tabular}{|c|c|c|c|c|c|c|c|c|}
\hline \multirow{3}{*}{$\begin{array}{l}\text { Litter } \\
(\mathrm{g})\end{array}$} & $\begin{array}{c}\text { Tmed } \\
\left({ }^{\circ} \mathrm{C}\right)\end{array}$ & $\begin{array}{l}\text { Pacum } \\
(\mathrm{mm})\end{array}$ & $\begin{array}{l}\text { Tmed } \\
\left({ }^{\circ} \mathrm{C}\right)\end{array}$ & $\begin{array}{l}\text { Pacum } \\
(\mathrm{mm})\end{array}$ & $\begin{array}{c}\text { Tmed } \\
\left({ }^{\circ} \mathrm{C}\right)\end{array}$ & $\begin{array}{c}\text { Pacum } \\
(\mathrm{mm})\end{array}$ & $\begin{array}{c}\text { Tmed } \\
\left({ }^{\circ} \mathrm{C}\right)\end{array}$ & $\begin{array}{c}\text { Pacum } \\
(\mathrm{mm})\end{array}$ \\
\hline & \multicolumn{8}{|c|}{ Mata Alta } \\
\hline & \multicolumn{2}{|c|}{ Year $1 \times$ Study period } & \multicolumn{2}{|c|}{ Year $2 \times$ Study period } & \multicolumn{2}{|c|}{$\begin{array}{c}\text { Year } 1 \times \text { Historical } \\
\text { series }\end{array}$} & \multicolumn{2}{|c|}{$\begin{array}{c}\text { Year } 2 \times \text { Historical } \\
\text { series }\end{array}$} \\
\hline Leaf & $0.51 \mathrm{~ns}$ & $0.75^{\star *}$ & $0.73^{\star \star}$ & $0.69^{*}$ & $0.62^{*}$ & $0.85^{\star}$ & $0.69^{*}$ & $0.75^{\star}$ \\
\hline Total & $0.12 \mathrm{~ns}$ & $0.35 \mathrm{~ns}$ & $0.55 \mathrm{~ns}$ & $0.43 \mathrm{~ns}$ & $0.42 \mathrm{~ns}$ & $0.67^{\star}$ & $0.46 \mathrm{~ns}$ & $0.55 \mathrm{~ns}$ \\
\hline \multirow{3}{*}{$\begin{array}{l}\text { Litter } \\
\text { (g) }\end{array}$} & $\begin{array}{c}\text { Tmed } \\
\left({ }^{\circ} \mathrm{C}\right)\end{array}$ & $\begin{array}{l}\text { Pacum } \\
(\mathrm{mm})\end{array}$ & $\begin{array}{l}\text { Tmed } \\
\left({ }^{\circ} \mathrm{C}\right)\end{array}$ & $\begin{array}{c}\text { Pacum } \\
(\mathrm{mm})\end{array}$ & $\begin{array}{c}\text { Tmed } \\
\left({ }^{\circ} \mathrm{C}\right)\end{array}$ & $\begin{array}{c}\text { Pacum } \\
(\mathrm{mm})\end{array}$ & $\begin{array}{c}\text { Tmed } \\
\left({ }^{\circ} \mathrm{C}\right)\end{array}$ & $\begin{array}{c}\text { Pacum } \\
(\mathrm{mm})\end{array}$ \\
\hline & \multicolumn{8}{|c|}{ Mussununga } \\
\hline & \multicolumn{2}{|c|}{ Year 1} & \multicolumn{2}{|c|}{ Year 2} & \multicolumn{2}{|c|}{$\begin{array}{c}\text { Year } 1 \times \text { Historical } \\
\text { series }\end{array}$} & \multicolumn{2}{|c|}{$\begin{array}{c}\text { Year } 2 \times \text { Historical } \\
\text { series }\end{array}$} \\
\hline Leaf & $0.18 \mathrm{~ns}$ & $-0.22 \mathrm{~ns}$ & $0.71^{\star \star}$ & $0.84^{\star \star}$ & $0.14 \mathrm{~ns}$ & $0.54 \mathrm{~ns}$ & $0.73^{*}$ & $0.75^{\star}$ \\
\hline Total & $-0.10 \mathrm{~ns}$ & $0.34 \mathrm{~ns}$ & $0.92^{\star *}$ & $0.76^{\star *}$ & $0.23 \mathrm{~ns}$ & $0.57 \mathrm{~ns}$ & $0.86^{\star}$ & $0.77^{\star}$ \\
\hline
\end{tabular}

ns: Non-significant correlation. ${ }^{*}$ Significant correlation at $\mathrm{P}=0.05 .{ }^{* *}$ Significant correlation at $\mathrm{P}=0.01$.

significant positive correlation between the data from the historical series and the precipitation data from year $1(0.63, \mathrm{P}<0.05)$ and year $2(0.83, \mathrm{P}<0.05)$, and temperature from historical series and temperature from both years 1 and $2(0.94, \mathrm{P}<0.05)$.

\subsection{Nutrients in total fine litterfall}

The mean values for nitrogen concentration and content were both higher in the total fine litterfall in the Mata Alta area, compared to the Mussununga area
(Table 4). On the other hand, there were no significant differences between the areas in terms of phosphorus concentration and content in the total fine litterfall.

\subsection{Leaf litter decomposition}

We observed contrasting patterns of leaf litter decomposition in the two phytophysiognomies studied. There was a rapid loss of leaf litter mass during the first 60 days in the Mata Alta, with only approximately $82 \%$ of the original mass remaining after this period (Figure 3 ). 
Table 4. Concentration and content of nitrogen $(\mathrm{N})$ and phosphorus $(\mathrm{P})$ in total fine litterfall, in the Mata Alta and Mussununga phytophysiognomies within the upland (Tabuleiro) forests of the Vale Natural Reserve, in Linhares, Espírito Santo State, Brazil.

\begin{tabular}{|c|c|c|c|c|}
\hline \multirow{2}{*}{ Phytophysiognomy } & $\mathbf{N}$ & $\mathbf{P}$ & $\mathbf{N}$ & $\mathbf{P}$ \\
\hline & \multicolumn{2}{|c|}{$\mathrm{g} \mathrm{kg}^{-1}$} & \multicolumn{2}{|c|}{$\mathrm{kg} \mathrm{ha}^{-1}$ year-1 $^{-1}$} \\
\hline Mata Alta & $14.71 \mathrm{~A}$ & $0.95 \mathrm{~A}$ & $212.05 \mathrm{~A}$ & $13.84 \mathrm{~A}$ \\
\hline Mussununga & $9.54 \mathrm{~B}$ & $0.91 \mathrm{~A}$ & $106.68 \mathrm{~B}$ & $10.20 \mathrm{~A}$ \\
\hline
\end{tabular}

${ }^{*}$ The values indicate the means obtained from three replicates. Values followed by different letters indicate significant differences between the phytophysiognomies, as determined by the parametric Student $t$ test or the nonparametric Mann-Whitney test $(\mathrm{P}<0.05)$.

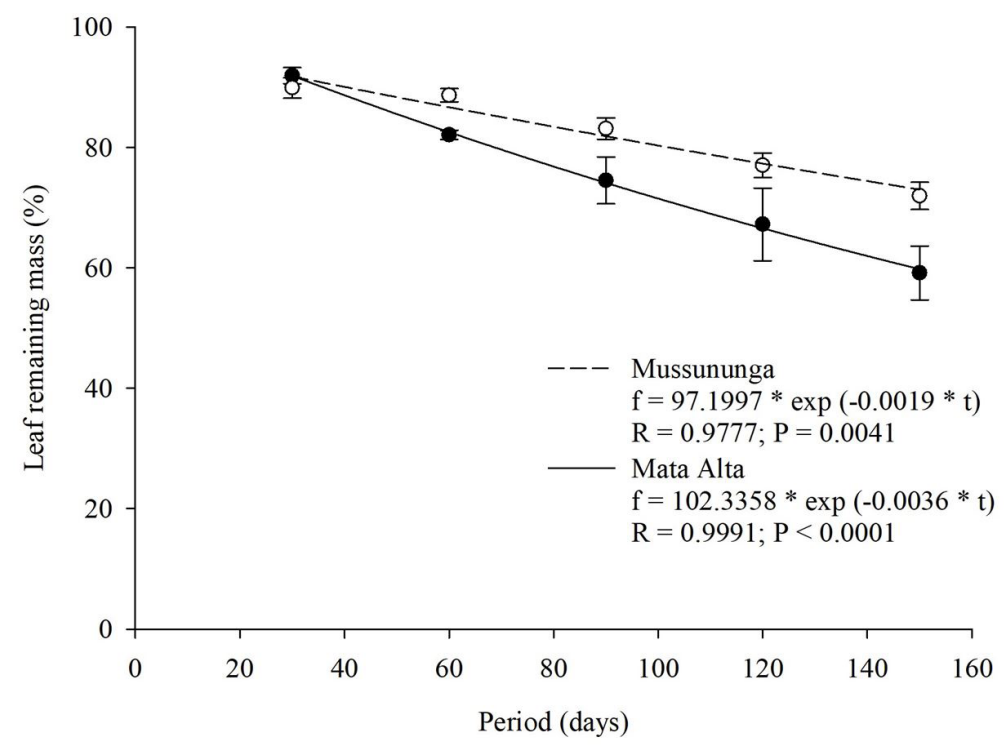

Figure 3. Decomposition of the leaf litter fraction (g) during the study period (150 days) in the Mata Alta and Mussununga phytophysiognomies within the upland (Tabuleiro) forests of the Vale Natural Reserve, in Linhares, Espírito Santo State, Brazil.

In the Mussununga forest, however, approximately $89 \%$ of the original leaf litter mass was still present after the first 60 days.

After 150 days, the remaining leaf litter material in the Mata Alta forest was only approximately $59 \%$ of the original mass, while $72 \%$ of the original leaf litter mass remained in the Mussununga forest (Figure 3). The value of the decomposition constant $\mathrm{k}$ in the Mata Alta was $0.0036 \mathrm{~g} \mathrm{~g}^{-1} \mathrm{day}^{-1}$, that is, 2 times higher than that calculated for the Mussununga forest $\left(0.0019 \mathrm{~g} \mathrm{~g}^{-1}\right.$ day $\left.^{-1}\right)$. As such, the half-life $\left(\mathrm{T}_{1 / 2}\right)$ of leaf litter in the Mussununga forest was 365 days, approximately twice that observed in the Mata Alta (193 days). The leaf mass decrease equations in the Mata Alta and Mussununga forests showed significant $(\mathrm{P}<0.05)$ and high values for correlation coefficients $(\mathrm{R}>0.80)$.

\section{DISCUSSION}

\subsection{Fine litterfall}

The higher total annual litterfall in the Mata Alta was a result of the more robust structure of that phytophysiognomy, which, in turn, led to the differences between the areas in terms of primary productivity (Capellesso et al., 2016) related to their contrasting edaphic characteristics. The soil in the Mussununga area is sandy and nutrient-poor when compared to the Mata Alta soil (Garay et al., 1995) due to cation leaching. The primary productivities of tropical forests are lower in soils presenting lower phosphorus, potassium, and calcium availability (Moraes et al., 1999; Chave et al., 2010; Baribault et al., 2012). The annual fine litterfall in Mata Alta and Mussununga forests were both higher 
when compared to the estimated means for other Seasonal Forest areas and for the different Atlantic Forest phytophysiognomies (Table 5).

As mentioned earlier, the Mussununga area presents high floristic similarity with sandy, nearshore restinga vegetation (Giaretta et al., 2013). In spite of this, and regardless of both ecosystems growing on nutrient-poor sandy soils, the total litterfall of the Mussununga area was $64 \%$ higher (mean of the study years) than the mean value for restinga forests (Table 4). This finding demonstrates, once again, the influence of arboreal community structure on litterfall. In fact, the canopy in the Mussununga area is higher (7-15 $\mathrm{m}$ ) when compared with non-flooding areas of restinga (4-7 m) on Ilha do Cardoso and Ilha do Mel (Moraes et al., 1999). On the other hand, the mean annual total litterfall in the Mussununga forest was very close to a dune forest in the Restinga da Marambaia (6.8 $\left.\mathrm{Mg} \mathrm{ha}^{-1}\right)$ whose canopy height (8-15 m) (Camara et al., 2018a) was similar to the Mussununga forest.
The higher relative contribution of the leaf fraction to the annual total litterfall in both areas represents a pattern commonly reported in the literature (Table 4). The sandy textures of Mussununga soils apparently also influenced the higher contribution of leaves to total litterfall in relation to the Mata Alta forest. Soils with higher sand content and lower clay content retain less water (Pastor \& Post, 1986) and allow increased litter deposition from plants (Souza et al., 2019). Thus, the arboreal community in the Mussununga phytophysiognomy likely demonstrates higher leaf abscission than the Mata Alta area to reduce water loss through evapotranspiration.

Litterfall occurred continuously during the present study, although we observed higher deposition during the rainy season, probably reflecting an increase in leaf renewal, which occurs simultaneously with growth (due to the higher availability of water in the soil). Additionally, high winds are very common during the rainy season, as well as torrential downpours, whose

Table 5. Annual total litterfall $\left(\mathrm{Mg} \mathrm{ha}^{-1}\right.$ year $\left.^{-1}\right)$ and the relative contribution of the leaf fraction (\%) in different Atlantic Forest phytophysiognomies (SSDF: Seasonal Semi-Deciduous Forest; SDF: Seasonal Deciduous Forest; NDF: Non-Deciduous Forest; RE: Restinga), Brazil.

\begin{tabular}{|c|c|c|c|c|}
\hline Phytophysiognomy & Site & Total litterfall & Leaves & Reference \\
\hline \multirow[t]{6}{*}{ SSDF } & Linhares, ES & $12.1(\mathrm{MA})^{1}$ & $60^{1}$ & This study \\
\hline & & $9.2(\mathrm{MU})^{1}$ & $68^{1}$ & \\
\hline & Interior of $\mathrm{PR}$ & 8.2 & 79 & Pimenta et al. (2011) \\
\hline & Pinheiral, RJ & $6.6(\mathrm{FSEI})^{2}$ & $84(\mathrm{FSEI})^{2}$ & Menezes et al. (2010) \\
\hline & & $7.4(\text { FSEM })^{2}$ & $75(\text { FSEM })^{2}$ & \\
\hline & & $11.0(\text { FSEA })^{2}$ & $53(\text { FSEA) })^{2}$ & \\
\hline SDF & Itaara, RS & 5.9 & 63 & Marafiga et al. (2012) \\
\hline Mean & & 8.6 & 69 & \\
\hline \multirow[t]{8}{*}{$\mathrm{NDF}$} & Rio de Janeiro, RJ & 5.6 & 61 & Freire et al. (2014) \\
\hline & Ilha do Cardoso, SP & 6.3 & 70 & Moraes et al. (1999) \\
\hline & Guaraqueçaba, PR & $6.4(\text { Site } 1)^{3}$ & $69(\text { Site } 1)^{3}$ & Scheer et al. (2011) \\
\hline & & $3.0(\text { Site } 2)^{3}$ & $80(\text { Site } 2)^{3}$ & \\
\hline & Guaraqueçaba, PR & 8.4 & 73 & Sloboda et al. (2017) \\
\hline & Antonina, PR & $7.7(\mathrm{FS}-1)^{4}$ & $74(\mathrm{FS}-1)^{4}$ & Bianchin et al. (2016) \\
\hline & & $7.1(\mathrm{FS}-2)^{4}$ & $67(\mathrm{FS}-2)^{4}$ & \\
\hline & & $8.1(\mathrm{FS}-3)^{4}$ & $66(\text { FS-3) })^{4}$ & \\
\hline Mean & & 6.6 & 70 & \\
\hline \multirow[t]{4}{*}{ RE } & Ilha do Cardoso, SP & 3.9 & 75 & Moraes et al. (1999) \\
\hline & Ilha do Mel, PR & 5.1 & 75 & Pires et al. (2006) \\
\hline & Restinga da Marambaia, RJ & 6.8 & 70 & Camara et al. (2018a) \\
\hline & Restinga da Marambaia, RJ & $7.6^{5}$ & $58^{5}$ & Pereira et al. (2012) \\
\hline Mean & & 5.9 & 70 & \\
\hline General mean & & 7.2 & 69 & \\
\hline
\end{tabular}

${ }^{1} \mathrm{MA}$ and MU: Mata Alta and Mussununga, respectively. ${ }^{2}$ FSEI, FSEM, and FSEA: secondary forest initial, medium, and advanced stage. ${ }^{3}$ Site 1 and Site 2: most advanced and least advanced secondary successional stage, respectively. ${ }^{4}$ FS-1, FS-2, and FS-3: Less evolved, intermediate and more evolved secondary forests, respectively. ${ }^{5}$ Periodically flooded forest. 
mechanical impacts tend to produce high litterfall (Camara et al., 2018b).

\subsection{Nutrients in total fine litterfall}

The highest nutrient input from total fine litterfall to the soil was proportional to the higher amount of litterfall in the Mata Alta area. This pattern is commonly observed in the literature (Pimenta et al., 2011; Sloboda et al., 2017). The low natural fertility of the soil in the Mussununga forest also influenced the lower concentrations of nutrients in its litterfall (Moraes et al., 1999). The nitrogen concentration in total fine litterfall in the Mussununga area was much lower and approached the value observed in the restinga located in Cardoso Island, SP (Table 6).

On the other hand, nitrogen concentration in total fine litterfall in the area of Mata Alta approached the estimated mean value for different areas of Semi-Deciduous and Deciduous Seasonal Forest, and Non-Deciduous Forest (Table 5). Regarding the phosphorus concentration, both areas of the present study showed high values compared to the different Atlantic Forest phytophysiognomies.

\subsection{Leaf litter decomposition}

Litter decomposition was faster in the first trimester, with a subsequent slowing in both phytophysiognomies. The initial phase of fast decomposition, which is due to the high content of rapidly decomposable components, is followed by a lower rate of mass loss due to remaining, more resistant structures (Matos et al., 2011). There was an adequate adjustment of the data obtained from the decomposition experiment to the model of leaf litter mass decay.

Results obtained in the different areas of Atlantic Forest and restingas corroborated the relatively rapid rate of decomposition observed in the Mata Alta (Table 7). On the other hand, leaf litter decomposition in the Mussununga area was considered slow, with the decomposition rate being close to the value observed in a periodically flooded area of restinga forest (Pereira et al., 2012). The low nutrient quality of litter (Castanho \& Oliveira, 2008; Pereira et al., 2012) can retard its breakdown and slow its decomposition in some forest ecosystems (Zhang et al., 2008) such as in restingas (Camara et al., 2018a). In fact, the same pattern occurred in the Mussununga area, where lower nitrogen concentrations were observed, which led to lower rates of leaf litter decomposition compared to the Mata Alta area. Vegetation growing on sandy soils presented lower nitrogen and phosphorus concentrations in the leaves than the vegetation established on clayey soils (Thompson et al., 1992).

According to Garay et al. (1995), the litter standing stock on the soil surface in the Mussununga area $\left(512 \mathrm{~kg} \mathrm{ha}^{-1}\right)$ was almost four times greater than in the Mata Alta area $\left(141 \mathrm{~kg} \mathrm{ha}^{-1}\right)$, resulting in greater organic material stock in the soil of the former

Table 6. Nitrogen $(\mathrm{N})$ and phosphorus $(\mathrm{P})$ concentrations $\left(\mathrm{g} \mathrm{kg}^{-1}\right)$ in total fine litterfall in different Atlantic Forest phytophysiognomies (SSDF: Seasonal Semi-Deciduous Forest; SDF: Seasonal Deciduous Forest; NDF: NonDeciduous Forest; RE: Restinga), Brazil.

\begin{tabular}{|c|c|c|c|c|}
\hline Phytophysiognomy & Site & $\mathbf{N}$ & $\mathbf{P}$ & Reference \\
\hline \multirow[t]{3}{*}{ SSDF } & Linhares, ES & $14.71(\mathrm{MA})^{1}$ & $0.95^{1}$ & This study \\
\hline & & $9.54(\mathrm{MU})^{1}$ & $0.91^{1}$ & \\
\hline & Interior of $\mathrm{PR}$ & 19.78 & 0.22 & Pimenta et al. (2011) \\
\hline SDF & Itaara, RS & $20.10^{2}$ & $0.80^{2}$ & Marafiga et al. (2012) \\
\hline Mean & & 16.03 & 0.72 & \\
\hline \multirow[t]{4}{*}{ NDF } & Ilha do Cardoso, SP & $17.53^{3}$ & $0.85^{3}$ & Moraes et al. (1999) \\
\hline & Guaraqueçaba, PR & $14.45(\text { Site } 1)^{4}$ & $0.96(\text { Site } 1)^{4}$ & Scheer et al. (2011) \\
\hline & & $11.58(\text { Site } 2)^{4}$ & $0.78(\text { Site } 2)^{4}$ & \\
\hline & Guaraqueçaba, PR & $18.50^{3}$ & $0.93^{3}$ & Sloboda et al. (2017) \\
\hline Mean & & 15.52 & 0.88 & \\
\hline RE & Ilha do Cardoso, SP & $9.38^{3}$ & $0.38^{3}$ & Moraes et al. (1999) \\
\hline General mean & & 15.07 & 0.75 & \\
\hline
\end{tabular}

${ }^{1} \mathrm{MA}$ and MU: Mata Alta and Mussununga, respectively. ${ }^{2}$ Mean obtained from total litterfall of several species. ${ }^{3}$ Mean obtained from different fractions (leaves, twigs, reproductive organs and fragments) of fine litterfall. ${ }^{4}$ Site 1 and Site 2: most advanced and least advanced secondary successional stage, respectively. 
Table 7. Values of the leaf litter decomposition rates $\left(\mathrm{k}, \mathrm{g} \mathrm{g}^{-1}\right.$ day $\left.{ }^{-1}\right)$ and half-life $\left(\mathrm{T}_{1 / 2}\right.$, days) obtained from studies with litterbags in different Atlantic Forest phytophysiognomies (SSDF: Seasonal Semi-Deciduous Forest; SDF: Seasonal Deciduous Forest; NDF: Non-Deciduous Forest; RE: Restinga), Brazil.

\begin{tabular}{|c|c|c|c|c|}
\hline Phytophysiognomy & Site & k & $T_{1 / 2}$ & Reference \\
\hline \multirow[t]{7}{*}{ SSDF } & Linhares, ES & $0.0036(\mathrm{MA})^{1}$ & $193^{1}$ & This study \\
\hline & & $0.0019(\mathrm{MU})^{1}$ & $365^{1}$ & \\
\hline & Pinheiral, RJ & $0.0044(\mathrm{FSEI})^{2}$ & $157(\mathrm{FSEI})^{2}$ & Menezes et al. (2010) \\
\hline & & $0.0038(\mathrm{FSEM})^{2}$ & $182(\text { FSEM })^{2}$ & \\
\hline & & $0.0064(\text { FSEA })^{2}$ & $53(\text { FSEA })^{2}$ & \\
\hline & Além Paraíba, MG & 0.0026 & 266 & Cunha et al. (2013) \\
\hline & Vitória da Conquista, BA & $\begin{array}{l}0.0023(\mathrm{NF})^{3} \\
0.0019(\mathrm{NFP})^{3}\end{array}$ & $\begin{array}{c}301(\mathrm{NF})^{3} \\
365(\mathrm{NFP})^{3}\end{array}$ & Silva et al. (2014) \\
\hline Mean & & 0.0034 & 235 & \\
\hline \multirow[t]{2}{*}{$\mathrm{NDF}$} & São Paulo, SP & 0.0027 & 248 & Ferreira et al. (2014) \\
\hline & Pinheiral, RJ & $\begin{array}{l}0.0032 \text { (edge) } \\
0.0042 \text { (interior) }\end{array}$ & $\begin{array}{c}216 \text { (edge) } \\
165 \text { (interior) }\end{array}$ & Pereira et al. (2013) \\
\hline Mean & & 0.0034 & 210 & \\
\hline $\mathrm{RE}$ & Restinga da Marambaia, RJ & $0.0015^{4}$ & $462^{4}$ & Pereira et al. (2012) \\
\hline General mean & & 0.0032 & 248 & \\
\hline
\end{tabular}

${ }^{1} \mathrm{MA}$ and MU: Mata Alta and Mussununga, respectively. ${ }^{2}$ FSEI, FSEM, and FSEA: secondary forest initial, medium, and advanced stage. ${ }^{3} \mathrm{NF}$ and PNF: native forest and plantation of native forest species. ${ }^{4}$ Periodically flooded forest.

phytophysiognomy (21.9 $\mathrm{Mg} \mathrm{ha}^{-1}$ vs. $6.1 \mathrm{Mg} \mathrm{ha}^{-1}$ ). The high litter accumulation on the soil surface seen in the Mussununga area (which depends on the relationship between litterfall and its decomposition) reflects its slow decomposition there, in contrast to the results of the Mata Alta area, which showed higher rates of both litterfall and decomposition. As a result, the higher litter accumulation in the Mussununga area serves as a reservoir of mineral nutrients overlying a nutrient-poor sandy soil (therefore similar to restinga soils).

There is an equilibrium between the low litterfall rate and slow decomposition in restinga areas that minimizes nutrient losses through the gradual release of nutrients from the organic material (Camara et al., 2018a). The slow decomposition reflects a litter poor in nutrients, as seen in the present study, but rich in lignin, with elevated lignin:nitrogen and/or carbon:nitrogen ratios (Bonanomi et al., 2013). The leaves demonstrate higher lignification as a mechanism to minimize water losses through evapotranspiration, in restinga (Pereira et al., 2012).

Garay et al. (1995) found that approximately $30 \%$ of the fine roots of the plants growing in the Mussununga area were present in the litter standing stock, however this was not observed in the Mata Alta. The presence of fine roots $(78-94 \%$ of total) in the topsoil ( $0.00-0.05 \mathrm{~cm})$ in tropical forests (Rosado et al., 2011) represents an important mechanism linked to the optimization of nutrient absorption through direct absorption from decomposing litter. This ecological mechanism minimizes nutrient losses through leaching, especially in nutrient-poor sandy soils, thus favoring their retention in the ecosystem.

\section{CONCLUSIONS}

Fine aboveground litterfall, with a predominant leaf fraction, was continuous throughout the study years. However, higher litter deposition occurred in the rainy season in both phytophysiognomies.

Lower values for fine litterfall, nutrient input, and leaf litter decomposition were observed in the Mussununga area, probably functioning as nutrient conservation strategies, and thereby contributing to the ecological functioning of this ecosystem where soil fertility was lower than in the Mata Alta. Thus, the results corroborated the hypothesis that such aspects of nutrient cycling differ between these two contiguous physiognomies of Atlantic Forest with different floristic and edaphic conditions.

\section{ACKNOWLEDGEMENTS}

Fundação de Amparo à Pesquisa e Inovação do Espírito Santo. 


\section{SUBMISSION STATUS}

Received: 15 mar., 2019

Accepted: 13 nov., 2019

\section{CORRESPONDENCE TO}

\section{Marcos Gervasio Pereira}

Universidade Federal Rural do Rio de Janeiro - UFRRJ, BR 465, Km 7, CEP 23890-000, Seropédica, RJ, Brasil

e-mail: mgervasiopereira01@gmail.com

\section{FINANCIAL SUPPORT}

FAPES (Grant number 45461910/09).

\section{REFERENCES}

Aerts R. Climate, leaf litter chemistry and leaf litter decomposition in terrestrial ecosystems: a triangular relationship. Oikos 1997; 79(3): 439-449. http://dx.doi. org/10.2307/3546886.

Alvares CA, Stape JL, Sentelhas PC, Gonçalves JLM, Sparovek G. Koppen's climate classification map for Brazil. Meteorologische Zeitschrift (Berlin) 2013; 22(6): 711-728. http://dx.doi.org/10.1127/0941-2948/2013/0507.

Baribault TW, Kobe RK, Finley AO. Tropical tree growth is correlated with soil phosphorus, potassium, and calcium, though not for legumes. Ecological Monographs 2012; 82(2): 189-203. http://dx.doi.org/10.1890/11-1013.1.

Bianchin JE, Marques R, Britez RM, Capretz RL. Deposição de fitomassa em formações secundárias na Floresta Atlântica do Paraná. Floresta e Ambiente 2016; 23(4): 524-533. http://dx.doi.org/10.1590/2179-8087.134015.

Bonanomi G, Incerti G, Giannino F, Mingo A, Lanzotti $\mathrm{V}$, Mazzoleni S. Litter quality assessed by solid state ${ }^{13} \mathrm{C}$ NMR spectroscopy predicts decay rate better than $\mathrm{C} / \mathrm{N}$ and lignin/N ratios. Soil Biology \& Biochemistry 2013; 56: 40-48. http://dx.doi.org/10.1016/j.soilbio.2012.03.003.

Camara R, Pereira MG, Menezes LFT, Segall AB, Castro JSR. Litter dynamics in a forest dune at Restinga da Marambaia, RJ, Brazil. Floresta e Ambiente 2018a; 25(2): e20160046. http://dx.doi.org/10.1590/2179-8087.004616.

Camara R, Silva VD, Delaqua GCG, Lisbôa CP, Villela DM. Relação entre sucessão secundária, solo e serapilheira em uma Reserva Biológica no estado do Rio de Janeiro, Brasil. Ciência Florestal 2018b; 28(2): 674-686. http:// dx.doi.org/10.5902/1980509832066.

Capellesso ES, Scrovonski KL, Zanin EM, Hepp LU, Bayer C, Sausen TL. Effects of forest structure on litter production, soil chemical composition and litter-soil interactions. Acta Botanica Brasílica 2016; 30(3): 329335. http://dx.doi.org/10.1590/0102-33062016abb0048.

Castanho CT, Oliveira AA. Relative effect of litter quality, forest type and their interaction on leaf decomposition in south-east Brazilian forests. Journal of Tropical Ecology 2008; 24(2): 149-156. http://dx.doi.org/10.1017/ S0266467407004749.

Chave J, Navarrete D, Almeida S, Álvarez E, Aragão LEOC, Bonal D et al. Regional and seasonal patterns of litterfall in tropical South America. Biogeosciences 2010; 7(1): 43-55. http://dx.doi.org/10.5194/bg-7-43-2010.

Clima Tempo [online]. 2019 [cited 2019 Aug 17]. Available from: https://www.climatempo.com.br/climatologia/75/ linhares-es

Cunha FV No, Leles PSS, Pereira MG, Bellumath VGH, Alonso JM. Acúmulo e decomposição da serapilheira em quatro formações florestais. Ciência Florestal 2013; 23(3): 379-387. http://dx.doi.org/10.5902/1980509810549.

Ferreira ML, Silva JL, Pereira EE, Lamano-Ferreira APN. Litter fall production and decomposition in a fragment of secondary Atlantic Forest of São Paulo, SP, southeastern Brazil. Revista Árvore 2014; 38(4): 591-600. http://dx.doi. org/10.1590/S0100-67622014000400002.

Freire M, Scoriza RN, Piña-Rodrigues FCM. Influência do clima no aporte de serapilheira em uma Floresta Ombrófila Densa Montana. Agrária 2014; 9(3): 427-431. http://dx.doi.org/10.5039/agraria.v9i3a4142.

Garay I, Kindel A, Jesus RM. Diversity of humus forms in the Atlantic Forest ecosystems (Brazil). The Table-land Atlantic Forest. Acta Oecologica 1995; 16: 553-570.

Giaretta A, Menezes LFT, Pereira OJ. Structure and floristic pattern of a restinga in southeastern Brazil. Acta Botanica Brasílica 2013; 27(1): 87-107. http://dx.doi.org/10.1590/ S0102-33062013000100011.

Kaspari M, Garcia MN, Harms KE, Santana M, Wright SJ, Yavitt JB. Multiple nutrients limit litterfall and decomposition in a tropical forest. Ecology Letters 2008; 11(1): 35-43. PMid:18021246.

Lopes MIS, Domingos M, Struffaldi-de-Vuono Y. Ciclagem de nutrientes minerais. In: Sylvestre LS, Rosa MMT. Manual metodológico para estudos botânicos na Mata Atlântica. Seropédica: EDUR-UFRRJ; 2002. p. 72-102.

Marafiga JS, Viera M, Szymczak DA, Schumacher MV, Trüby P. Deposição de nutrientes pela serapilheira em um fragmento de Floresta Estacional Decidual no Rio Grande do Sul. Revista Ceres 2012; 59(6): 765-771. http://dx.doi. org/10.1590/S0034-737X2012000600005.

Matos ES, Mendonça ES, Cardoso IM, Lima PC, Freese D. Decomposition and nutrient release of leguminous plants in coffee agroforestry systems. Revista Brasileira de Ciência do Solo 2011; 35(1): 141-149. http://dx.doi. org/10.1590/S0100-06832011000100013. 
Menezes CEG, Pereira MG, Correia MEF, Anjos LHC, Paula RR, Souza ME. Aporte e decomposição da serapilheira e produção de biomassa radicular em florestas com diferentes estágios sucessionais em Pinheiral, RJ. Ciência Florestal 2010; 20(3): 439-452. http://dx.doi.org/10.5902/198050982059.

Moraes RMD, Delitti WBC, Vuono YS. Litterfall and litter nutrient content in two brazilian tropical forests. Brazilian Journal of Botany 1999; 22(1): 9-16. http://dx.doi. org/10.1590/S0100-84041999000100002.

Parsons SA, Congdon RA, Shoo LP, Valdez-Ramirez V, Williams SE. Spatial variability in litterfall, litter standing crop and litter quality in a Tropical Rain Forest Region. Biotropica 2014; 46(4): 378-386. http://dx.doi.org/10.1111/ btp.12113.

Pastor J, Post WM. Influence of climate, soil moisture, and succession on forest carbon and nitrogen cycles. Biogeochemistry 1986; 2(1): 3-27. http://dx.doi.org/10.1007/ BF02186962.

Peixoto AL, Silva IM, Pereira OJ, Simonelli M, Jesus RM, Rolim SG. Tableland Forests North of the Rio Doce: their representation in the Linhares Forest Reserve, Espírito Santo State, Brazil. Memoirs of the New York Botanical Garden 2008; 100: 369-372.

Pereira GHA, Pereira MG, Anjos LHC, Amorim TA, Menezes CEG. Decomposição da serrapilheira, diversidade e funcionalidade de invertebrados do solo em um fragmento de Floresta Atlântica. Bioscience Journal 2013; 29(5): 1317-1327.

Pereira MG, Silva NA, Paula RR, Menezes LFT. Aporte e decomposição de serapilheira em floresta periodicamente inundável na Restinga da Marambaia, RJ. Ciência Florestal 2012; 22(1): 59-67. http://dx.doi.org/10.5902/198050985079.

Pimenta JA, Rossi LB, Torezan JMD, Cavalheiro AL, Bianchini E. Produção de serapilheira e ciclagem de nutrientes de um reflorestamento e de uma floresta estacional semidecidual no sul do Brasil. Acta Botanica Brasílica 2011; 25(1): 53-57. http://dx.doi.org/10.1590/ S0102-33062011000100008.

Pires LA, Britez RM, Martel G, Pagano SN. Produção, acúmulo e decomposição da serapilheira em uma restinga da Ilha do Mel, Paranaguá, PR, Brasil. Acta Botanica Brasílica 2006; 20(1): 173-184. http://dx.doi.org/10.1590/ S0102-33062006000100016.

Rezende CP, Cantarutti RB, Braga JM, Gomide JA, Pereira $\mathrm{JM}$, Ferreira E et al. Litter deposition and disappearance in Brachiaria pastures in the Atlantic Forest region of the south of Bahia, Brazil. Nutrient Cycling in Agroecosystems 1999; 54(2): 99-112. http://dx.doi.org/10.1023/A:1009797419216.

Rosado BHP, Martins AC, Colomeu TC, Oliveira RS, Joly CA, Aidar MPM. Fine root biomass and root length density in a lowland and a montane tropical rain forest, SP, Brazil. Biota Neotropica 2011; 11(3): 203-209. http:// dx.doi.org/10.1590/S1676-06032011000300018.

Scheer MB, Gatti G, Wisniewski C. Nutrient fluxes in litterfall of a secondary successional alluvial rain forest in Southern Brazil. Revista de Biología Tropical 2011; 59(4): 1869-1882. PMid:22208099.

Silva HF, Barreto PAB, Sousa GTO, Azevedo GB, GamaRodrigues EF, Oliveira FGRB. Decomposição de serapilheira foliar em três sistemas florestais no Sudoeste da Bahia. Revista Brasileira de Biociências 2014; 12(3): 164-172.

Simonelli M, Souza AL, Peixoto AL, Silva AF. Floristic Composition and structure of the tree component of a Muçununga Forest in the Linhares Forest Reserve, Espírito Santo, Brazil. Memoirs of the New York Botanical Garden 2008; 100: 345-364.

Sloboda B, Marques R, Bianchin J, Blum H, Donha C, Silveira $\mathrm{F}$ et al. Litterfall and nutrient dynamics in a mature Atlantic Rainforest in Brazil. Floresta e Ambiente 2017; 24(0): e20160339. http://dx.doi.org/10.1590/21798087.033916

Souza SR, Veloso MDM, Espírito-Santo MM, Silva JO, Sánchez-Azofeifa A, Souza e Brito BG et al. Litterfall dynamics along a successional gradient in a Brazilian tropical dry forest. Forest Ecosystems 2019; 6(1): 35. http:// dx.doi.org/10.1186/s40663-019-0194-y.

Tedesco MJ, Gianello C, Bissani CA, Bohnen H, Volkweiss SJ. Análises de solo, plantas e outros materiais. 2. ed. Porto Alegre: Universidade Federal do Rio Grande do Sul; 1995.

Thomas RJ, Asakawa NM. Decomposition of leaf litter from tropical forage grasses and legumes. Soil Biology \& Biochemistry 1993; 25(10): 1351-1361. http://dx.doi. org/10.1016/0038-0717(93)90050-L.

Thompson J, Proctor J, Viana V, Milliken W, Ratter JA, Scott DA. Ecological studies on a Lowland Evergreen Rain Forest on Maraca Island, Roraima, Brazil. I. Physical environment, forest structure and leaf chemistry. Journal of Ecology 1992; 80(4): 689-703. http://dx.doi. org/10.2307/2260860.

Vitousek PM. Litterfall, nutrient cycling and nutrient limitation in tropical forests. Ecology 1984; 65(1): 285298. http://dx.doi.org/10.2307/1939481.

Zhang D, Hui D, Luo Y, Zhou G. Rates of litter decomposition in terrestrial ecosystems: global patterns and controlling factors. Journal of Plant Ecology 2008; 1(2): 85-93. http:// dx.doi.org/10.1093/jpe/rtn002.

Zhang H, Yuan W, Dong W, Liu S. Seasonal patterns of litterfall in forest ecosystem worldwide. Ecological Complexity 2014; 20: 240-247. http://dx.doi.org/10.1016/j. ecocom.2014.01.003. 